\title{
THE EFFECT OF ADDITION OF Lactobacillus plantarum S4512 ON THE MICROBIOLOGICAL AND CHEMICAL CHARACTERISTICS DURING SORGHUM (Sorghum bicolor L. Moench) FERMENTATION
}

\author{
Tyas Utami', Rifa Nurhayati², Endang Sutriswati Rahayu' ${ }^{1}$ \\ ${ }^{1}$ Department of Food and Agricultural Product Technology, Faculty of Agricultural Technology, Gadjah Mada University, \\ Jl. Flora No. 1, Bulaksumur, Yogyakarta 55281 \\ ${ }^{2}$ Center of Processes Development and Chemical Engineering, Indonesian Institute of Science, Gunung Kidul, Yogyakarta 55861 \\ Email: tys_utami@yahoo.com.sg
}

\begin{abstract}
The aim of this study was to investigate the population of selected bacteria and some chemical characteristics during sorghum fermentation with the addition of Lactobacillus plantarum S4512. Proteolytic L. plantarum S4512 isolated from natural sorghum fermentation was added into sorghum fermentation. Sorghum flour was mixed with sterile water $(1: 2 \mathrm{w} / \mathrm{v})$ and then was inoculated with $1 \% \mathrm{v} / \mathrm{v}$ (about $10^{9} \mathrm{CFU} / \mathrm{ml}$ ) culture of $L$. plantarum $\mathrm{S} 4512$. Fermentation was carried out at $37^{\circ} \mathrm{C}$ for 24 hours. As a control, natural sorghum fermentation without addition of a starter culture was carried out at $30^{\circ} \mathrm{C}$ for 24 hours. During fermentation time, the amount of bacteria, acid producing bacteria, coliform and proteolytic bacteria were monitored. The titratable acidity, $\mathrm{pH}$, soluble protein, and proteolytic activity were also measured. Addition of L. plantarum S4512 increased significantly the initial population of total bacteria, lactic acid bacteria and proteolytic bacteria to $10^{7} \mathrm{CFU} / \mathrm{ml}$ and suppressed the growth of coliforms indicated by siginificantly decline of coliforms population after $6 \mathrm{~h}$ fermentation. The production of acid was doubled of that in the natural fermentation resulted in the lower $\mathrm{pH}$ to 3.14. Both natural sorghum fermentation and that with addition of proteolytic L. plantarum $\mathrm{S} 4512$ showed some proteolytic activities during fermentation.
\end{abstract}

Keywords: Lactic acid bacteria, sorghum fermentation, proteolytic activity

\section{INTRODUCTION}

Sorghum (Sorghum bicolor L. Moench) is one of the major food crops of the semiarid regions of Africa and Asia. Compared to other major cereal crops, sorghum has a distinct advatage of being drough-resistant. In Indonesia, especially in the province of East Nusa Tenggara, farmers cultivate sorghum as a staple food crop for consumption, thus sorghum is an important source of energy, protein, vitamins and minerals for people in this region.

A nutritional constraint to the use of sorghum as food is the lower protein and starch digestibility than normal maize flour, especially after cooking (Zhang and Hamaker, 1998; Doudu et al., 2003; Elkhalifa et al., 2006; De MesaStonestreet et al., 2010). Some studies, have shown that sorghum fermentation with naturally-occuring microflora improves the nutritional quality of sorghum. Fermentation increased the protein solubility of sorghum flour in the acidic range, increased oil-binding capacity, emulsifying capacity and emulsifying stability, while it decreased the waterbinding capacity (Elkhalifa et al., 2005). Starch granules in non-fermented sorghum flours are completely enclosed in a very compact protein matrix. Elkhalifa et al. (2006) found that based on the scanning electron microscopy study, the structure of the protein coating was disappeared in the fermented sorghum, leading to the release of the small starch granules. It indicates the involvement of proteolytic enzymes in sorghum fermentation. Improvement of the in vitro protein digestibility of Togwa (a sorghum based fermented food in Tanzania), suggests that proteolysis takes place during the preparation of the product (Mugula et al., 2003b).

Kunene et al. (1999) found that sorghum powder was a source of E. coli, spore forming bacteria such as B. cereus and $C$. perfringens, and lactic acid bacteria. Traditionally, the naturally occuring microorganisms in sorghum flour are utilized in these fermentation. The microflora of fermented sorghum consisted of lactic acid bacteria, coliforms, other acid-producing bacteria, yeasts and molds (Mohammed et al., 1991). Lactic acid bacteria were the dominant microflora and their number increased during sorghum fermentation (Mugula et al., 2003; Abdel-Rahman et al., 2010). The process of fermentation was found to be capable of significantly 
reducing the incidence of Gram negative bacteria and nonsporing bacterial pathogen (Kunene et al., 1999).

In this study, Lactobacillus plantarum S4512 which has a proteolytic activity isolated from natural fermentation of sorghum was addded to sorghum flour fermentation. The purpose of this work was to evaluate the use L. plantarum S4512 on the population of selected bacteria and chemical characteristics during during fermentation.

\section{MATERIALS AND METHODS}

\section{Preparation of Sorghum Flour}

Local variety of sorghum was obtained from a farmer in Belu, East Nusa Tenggara, Indonesia. Sorghum grains were milled to pass a $40-$ mesh screen.

\section{Sorghum Flour Fermentation}

Sorghum flour fermentation was carried out in the traditional way used by Sudanese housewives with some modifications (Mohammed et al., 1991). Sorghum flour was mixed with sterile distiled water in a 1:2 (w/v) ratio. The mixture was incubated at $30^{\circ} \mathrm{C}$ for $24 \mathrm{~h}$ in a sterile covered jar. This natural sorghum fermentation was performed by the original microorganisms present in the flour. Sorghum fermentation with addition of proteolytic lactic acid bacteria isolated from natural sorghum fermentation was initiated by inoculation of $1 \% \mathrm{v} / \mathrm{v}$ (about $10^{9} \mathrm{CFU} / \mathrm{ml}$ ) Lactobacillus plantarum S4512 into the mixture of sorghum flour with sterile distilled water (1:2 w/v ratio), and then incubated at $37^{\circ} \mathrm{C}$ for $24 \mathrm{~h}$. There was no sterilization of the sorghum flour. Thus sorghum fermentation was performed by the original microorganism present in the flour and the inoculated $L$. plantarum S4512.

The samples were withdrawn at $0,2,4,8,12,16$, 20 and $24 \mathrm{~h}$ of fermentation for microbial counts, and $\mathrm{pH}$ measurement. Titratable acidity, proteolytic acitivity, soluble protein and reducing sugar concentrations were also monitored during fermentation. For soluble protein and reducing sugar determinations, the fermented sorghum flour was dried using oven at $55-60^{\circ} \mathrm{C}$ until the moisture of the sorghum flour reached $11-13 \%$.

\section{Enumeration of Bacteria Population}

Population of bacteria during sorghum fermentation were determined using dilution and plating method. After further serially dilutions in $0.85 \% \mathrm{NaCl}$ solution, samples were plated in duplicate onto different agar media. Aerobic mesophilic bacteria were enumerated by spread plating onto Plate Count Agar (Oxoid). Numbers of lactic acid bacteria and coliforms were determined by pour plating method using
MRS (Criterion) with 1\% CaCO3 and Violet Red Bile Agar (VRBA) (Oxoid) respectively. Proteolytic bacteria were enumerated on skim milk agar. After $48 \mathrm{~h}$ of incubation at $37^{\circ} \mathrm{C}$, the colonies that appeared on the plates were counted and calculated as $\mathrm{CFU} / \mathrm{ml}$.

\section{Chemical Analysis}

The $\mathrm{pH}$ of the supernatant of the fermented material was measured using $\mathrm{pH}$ meter (Eutech Instruments $\mathrm{pH} 510$ ). The $\mathrm{pH}$ meter was calibrated using standard buffer solution at $\mathrm{pH}$ 4.0 and 7.0. The titratable acidity was measured by titrating the sample with $0.1 \mathrm{~N} \mathrm{NaOH}$ using $1 \%$ phenolphthalein as an indicator. Titratable acidity was calculated and expressed as percent lactic acid.

Reducing sugars were determined according to the Nelson-Somogyi method (Anonim, 1990). Sample preparation for soluble protein determination was based on Elkhalifa et al. (2005) with some modification. A one gram of sample was dispensed in $60 \mathrm{ml}$ ditilled water. The dispersion was continuously shaken in an orbithal shaker (Lab-line incubator-shaker) at $150 \mathrm{rpm}$ for $2 \mathrm{~h}$ at room temperature, and then filtered using whatman paper No 1 . The supernatant was collected and the soluble protein was determined by the method of Lowry-Follin.

\section{Proteolytic Activity Measurement}

Proteolytic acitivity of the supernatant of the fermented material was measured by the modifications of Nabrdalik et al., (2010) and Bruno et al., (2010). Casein Hammerstein $2 \%$ in phosphate buffer $\mathrm{pH} 7$ was used as a substrate for proteolytic activity analysis. Amount of $0.5 \mathrm{ml}$ Crude enzyme in $2.0 \mathrm{ml}$ phosphate buffer $\mathrm{pH} 6.0$ was pre-incubated for 1 minute at $40^{\circ} \mathrm{C}$, then it was added with $0.5 \mathrm{ml}$ substrate solution. Incubation was carried out at $40^{\circ} \mathrm{C}$ for 30 minutes. Enzymatic reaction was terminated by adding $5 \mathrm{ml}$ of $5 \%$ trichloro acetic acid (TCA), and kept at room temperature for 30 minutes. The mixture was centrifuged at $2000 \mathrm{rpm}$ for 15 minutes. One mililiter supernatant was added with $2.5 \mathrm{ml}$ $\mathrm{Na}_{2} \mathrm{CO}_{3} 0.4 \mathrm{M}$ and Follin reagent $(1: 1)$, incubated at $40^{\circ} \mathrm{C}$ for 20 minutes, and then determined the absorbance at $\lambda 753 \mathrm{~nm}$. One unit enzyme activity was expressed as the quantity of enzyme that release the equivalent of $\mu$ mole of tyrosine per minute under assay condition.

\section{RESULTS AND DISCUSSION}

\section{Bacterial Population During Sorghum Fermentation}

Figure 1A shows the population of selected bacteria during natural sorghum fermentation at $30^{\circ} \mathrm{C}$ for $24 \mathrm{~h}$ under aseptic conditions. The total plate count increased 
with increasing fermentation time from $3.21 \mathrm{log}$ CFU/ml to $8.88 \log \mathrm{CFU} / \mathrm{ml}$ at $24 \mathrm{~h}$. The initial lactic acid bacteria, coliforms and proteolytic bacteria were quite low i.e., 1.43; 2.85; and $2.88 \log \mathrm{CFU} / \mathrm{ml}$ respectively. As the fermentation progressed the number of lactic acid bacteria and proteolytic bacteria increased to $8.88 \log \mathrm{CFU} / \mathrm{ml}$ and $7.59 \log \mathrm{CFU} /$ $\mathrm{ml}$ respectively at the end of fermentation time. In natural sorghum fermentation, coliforms also increased significantly and reached the population of $7.98 \log \mathrm{CFU} / \mathrm{ml}$ at the end of fermentation time.
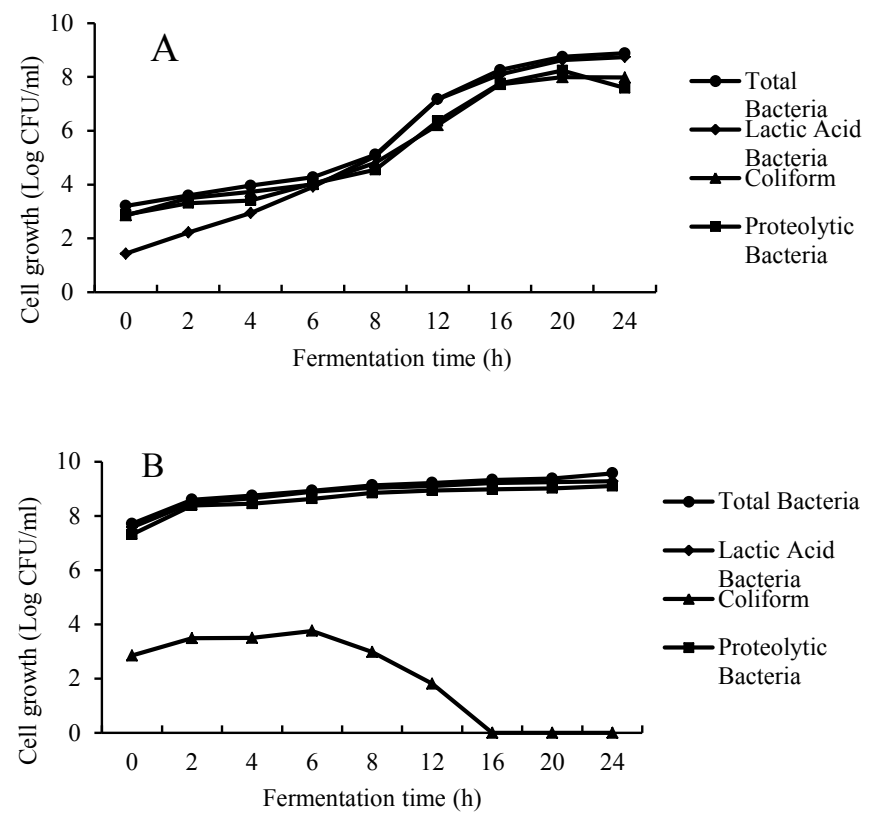

Figure 1. Bacterial growth during natural sorghum fermentation (A),and sorghum fermentation with addition of Lactobacillus plantarum S4512 (B)

Similar results were reported in the production of Kisra (Mohammed et al., 1991). The total plate count increased from about $5 \log \mathrm{CFU} / \mathrm{ml}$ to $9 \log \mathrm{CFU} / \mathrm{ml}$, lactic acid bacteria and coliforms constituted very low proportion (about $1 \log \mathrm{CFU} / \mathrm{ml}$ ) at the beginning of the fermentation time to $9 \log \mathrm{CFU} / \mathrm{ml}$ at $24 \mathrm{~h}$ fermentation. Coliforms increased about $2 \log$ cycles after $24 \mathrm{~h}$ fermentation of bushera (non-alcoholic beverage from sorghum). However, after 3 days, the coliform counts had decrease to less than $4 \log \mathrm{CFU} / \mathrm{ml}$ and were not detectable after the fourth day (Muyanja et al., 2003). This demonstrated the effect of acid production in the suppression of coliform during spontaneous fermentation of bushera. Abdel-Rahman et al., (2010) reported that Pediococcus pentosaceous was the dominant lactic acid bacterium throughout the fermentation process for the three sorghum varieties. Mugula et al. (2003) found that lactic acid bacteria was the dominant microbial population in sorghum fermentation with the population increased from 6 $\log \mathrm{CFU} / \mathrm{ml}$ to $9 \log \mathrm{CFU} / \mathrm{ml}$, and L. plantarum dominated the final stages of fermentation. In spontaneous sorghum fermentation, occuring microorganisms including lactic acid bacteria in sorghum flour is responsible to the fermentation process.

The growth of selected bacteria during sorghum fermentation with the addition of $L$. plantarum S4512 is presented in Figure 1B. addition $1 \% \mathrm{v} / \mathrm{v}$ L. plantarum S4512 in the sorghum flour markedly increased the initial number of lactic acid bacteria, proteolytic bacteria and total bacteria to $7.58 \log \mathrm{CFU} / \mathrm{ml}, 7.32 \mathrm{CFU} / \mathrm{ml}$ and $7.71 \mathrm{CFU} /$ $\mathrm{ml}$ respectively. It means that in the initial fermentation time, bacterial population was dominated by lactic acid bacteria which have proteolytic activity. As the fermentation progressed the number of lactic acid bacteria, proteolytic bacteria and total bacteria increased about two log cycles, reached 9.28 $\log \mathrm{CFU} / \mathrm{ml}, 9.10 \log \mathrm{CFU} / \mathrm{ml}$ and $9.57 \mathrm{log}$ $\mathrm{CFU} / \mathrm{ml}$ respectively. These growth profiles were similar to the traditional sorghum fermentation with inoculum in Sudan (Mohammed et al., 1991). Their growth rates were not as high as the ones in natural sorghum fermentation. High initial population made nutrition competition among microorganism and higher acid production also contributed to the lower growth rate. The proteolytic lactic acid bacteria dominated the initial sorghum flour fermentation due to the inoculation of proteolytic L. plantarum S4512. Here sorghum flour was not autoclaved prior to inoculation of L. plantarum S4512, thus the microorganims responsible to the sorghum fermentation were naturally occuring microorganism in sorghum flour and inoculated L. plantarum S4512.

The growth of coliforms suppressed during sorgum fermentation and no detectable coliform after $16 \mathrm{~h}$ fermentation. This could be due to the production of lactic acid by lactic acid bacteria and the low $\mathrm{pH}$ value. Figure $2 \mathrm{~B}$ shows that at $8 \mathrm{~h}$ fermentation with the addition of $L$. plantarum S4512 the acid content was almost doubled of the one in natural sorghum fermentation resulted in the drop of $\mathrm{pH}$ to 3.89. In the same time the number of coliforms started to decreased. Coliforms can not grow at the $\mathrm{pH}$ below 4.0 (Ray, 1996). In the natural sorghum fermentation (Figure 1A) the $\mathrm{pH}$ was still above 4.0 at the end of fermentation, thus, coliform could grow well. The similar result was reported by Hidayah (2010) which found that no coliforms were detected in the $16 \mathrm{~h}$ sorghum fermentation with addition of Lactobacillus acidophilus FNCC 050, in which the fermentation medium $\mathrm{pH}$ decreased to 3.49. The reduced levels of Gram negative bacteria and bacterial spores were also found in fermented sorghum samples indicated the effectiveness of fermentation in reducing these populations (Kunune et al., 1999). 


\section{pH and Titratable Acidity}

As the population of lactic acid bacteria increased from the initial low numbers and dominated the fermentation, the amount of acid produced increased with the concomitant drop in the $\mathrm{pH}$. The acid content increased from $0.16 \%$ to $0.47 \%$ at the end of the natural sorghum fermentation time, which resulted in the drop of $\mathrm{pH}$ from 6.13 to 4.75 (Figure 2A).

Significant increase in acid production occured in the sorghum fermentation with the addition of L. plantarum $\mathrm{S} 4512$, and at the end of fermentation, the acid content was doubled of the one in natural sorghum fermentation (Figure 2B). Consequently, the $\mathrm{pH}$ dropped faster during fermentation, from 5.99 to 4.28 in $6 \mathrm{~h}$ fermentation, and reached the $\mathrm{pH}$ of 3.41 at the end of fermentaion. The decrease in $\mathrm{pH}$ was a result of the production of acid by acid producing bacteria, especially lactic acid bacteria.
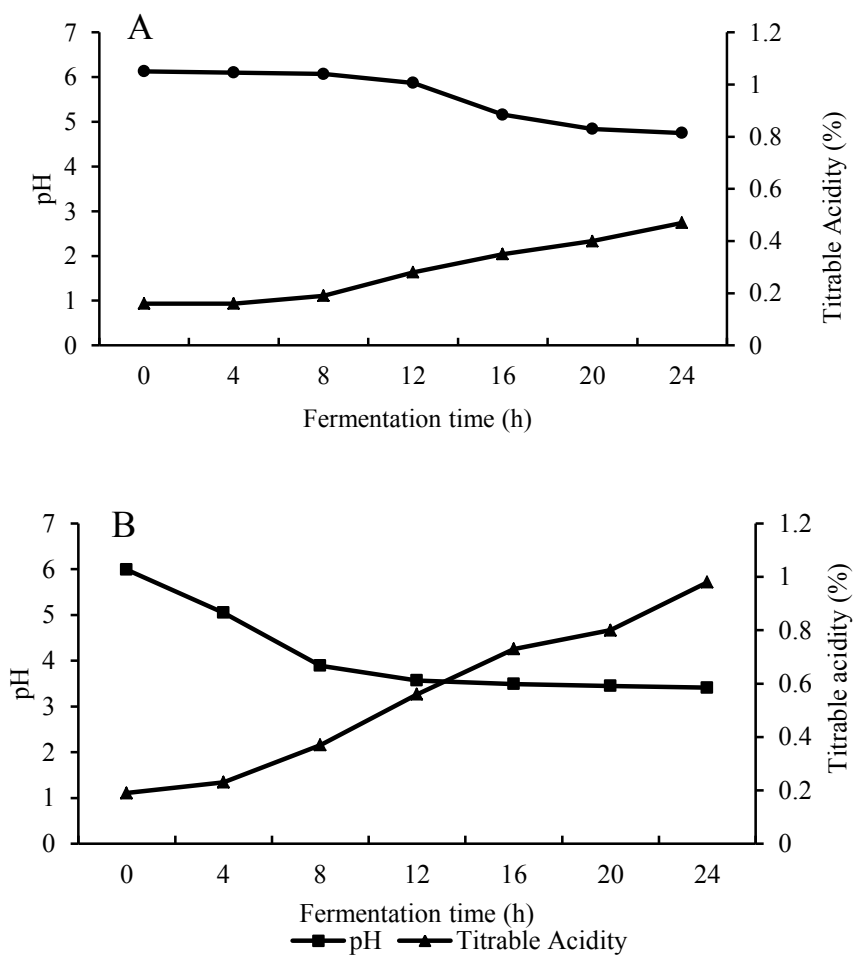

Figure 2. The changes of $\mathrm{pH}$ and titratable acidity during natural sorghum fermentation (A),and sorghum fermentation with addition of Lactobacillus plantarum S4512 (B)

The initial reducing sugar in the sorghum was $1.29 \%$ (Figure 3). The primary sugars present in sorghum grain are fructose, glucose, raffinose, sucrose and maltose (Anglani, 1998). These simple sugars utilized by microorganisms presented in sorghum fermentation for the growth and production of acid. The differences of acid production and $\mathrm{pH}$ during sorghum fermentation was affected by the metabolism activities of microorganism present in the fermented sorghum.
Sorghum flour inoculated with L. plantarum S4512 contained higher lactic acid bacteria in the beginning of fermentation time and the number increased throughout the fermentation time.

Corriea et al. (2005) reported that ${ }^{1} \mathrm{H}$ NMR spectra show decreases of glucose, fructose and maltose signals during fermentation of sorghum, and the increased of lactic acid, acetic acid and succinic acids. During $24 \mathrm{~h}$ fermentation of Togwa the $\mathrm{pH}$ decreased from 5,24-5.52 to 3.10-3.34. The organic acids detected during fermentation included lactate, succinate, pyruvate and DL-pyroglutamate, formate, citrate and uric acid (Mugula et al., 2003a). Some of $L$. plantarum isolated from Togwa were able to hydrolyse starch. Lactobacillus plantarum S4512 does not have amylolytic activities. It could be other microorganism naturally occured in sorghum flour responsible to the hydrolysis of sorghum starch.

\section{Proteolytic Activity}

In the natural sorghum fermentation, the initial proteolytic activity is $4.1 \times 10^{-3} \mathrm{U} / \mathrm{ml}$ and then increased to $8.1 \times 10^{-3} \mathrm{U} / \mathrm{ml}$ at $4 \mathrm{~h}$ fermentation and relatively constant until the end of fermentation time. It indicates that naturally microorganism in sorghum flour had proteolytic acitivity. Addition of proteolytic L. plantarum S4512 in sorghum fermentation shows similar initial proteolytic activity of the medium fermentation. It could be that in the initial fermentation time L. plantarum S4512 have not yet produced protease or its proteolytic activity was low. The proteolytic activity in sorghum fermentation with addition starter culture increased throughout the fermentation up to $16 \mathrm{~h}$ fermentation time and then decreased at the end of fermentation time (Figure 3).

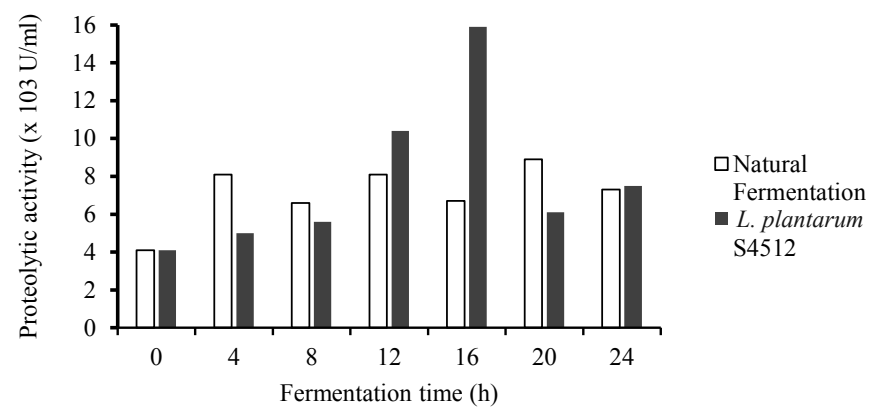

Figure 3. Proteolytic activity during natural sorghum fermentation ( $\square$ ), and sorghum fermentation with addition of Lactobacillus plantarum S4512 ( $\square)$

In-vitro improvement of protein digestibility in fermented sorghum reported by many researchers indicates that proteolysis take place during sorghum fermentation. 
Fermentation of sorghum flour increased the protein solubility of sorghum flour in $\mathrm{pH} \mathrm{2-4,} \mathrm{meanwhile} \mathrm{the} \mathrm{unfermented}$ sorghum flour had minimum protein solubility at $\mathrm{pH} 4$ (Elkhalifa et al., 2005). The high protein solubility at $\mathrm{pH} 4$ could be due to proteolytic activity. Elkhalifa et al., 2006) also reported that protein solubility and SDS-PAGE studies indicated that water-soluble proteins are the main target of hydrolysis during fermentation. Mugula et al., (2003b) reported more proteinase and aminopeptidase activities were observed in sorghum-based togwa prepared by natural fermentation than those fermented using starter cultures isolated from native product (L. brevis, L. cellobiosus, $L$. fermentum and L. plantarum). In their research, each starter culture was inoculated into sterile sorghum-based media, thus the enzyme activities were produced only by each lactic acid bacteria used as starter. Although all togwa prepared using starter cultures had proteolytic activity, their proteolytic activities were low and varied with different starter cultures. In natural fermentation, proteases were possibly produced by various naturally microorganisms in the sorghum resulted in higher proteolytic activity. In our study, sorghum was prepared without sterilization, thus in sorghum fermentation using addition of $L$. plantarum S4512, the proteolytic activity in the supernatant could be produced by natural microorganisms in sorghum flour and by L. plantarum S4512. Our results showed that proteolytic activities during natural sorghum fermentations and with starter culture were not markedly different. It could be that proteolytic activity produced by L. plantarum S4512 was not high enough to give significant increase in proteolytic activity in sorghum fermentation.

\section{Soluble Protein and Reducing Sugar Contents in Fermented Sorghum Flour}

The change of soluble protein and reducing sugar contents in fermented sorghum flour can be seen in Figure 4 and 5. Soluble protein content in fermented sorghum flour varied within the fermentation time, and relatively higher value was observed in fermentation with addition of L. plantarum S4512. Reducing sugar content in fermented sorghum flour from natural fermentation and the one with addition of L. plantarum S4512 increased with the increase in fermentation time up to $8 \mathrm{~h}$, and then decreased until the end of fermentation time.

Proteolytic producing microoorganisms in sorghum and L. plantarum S4512 produced proteases which degrade sorghum protein into smaller protein/peptides and amino acid thus increased the soluble protein. The free amino acids released will be utilized by microorganism for their growth. Correira et al. (2010) carried out sorghum fermentation with strains of lactic acid bacteria, and found various soluble protein, and free amino acid in fermented sorghum. Free

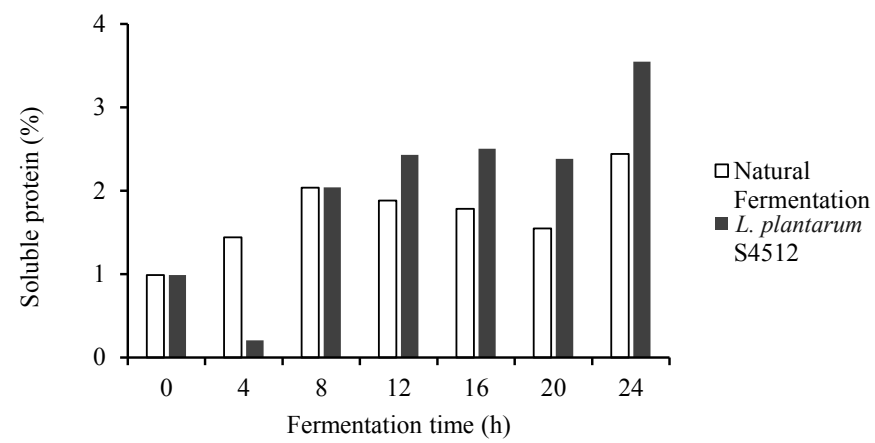

Figure 4. Protein solubility of sorghum flour during natural sorghum fermentation, and sorghum fermentation with addition of Lactrobacillus plantarum S4512

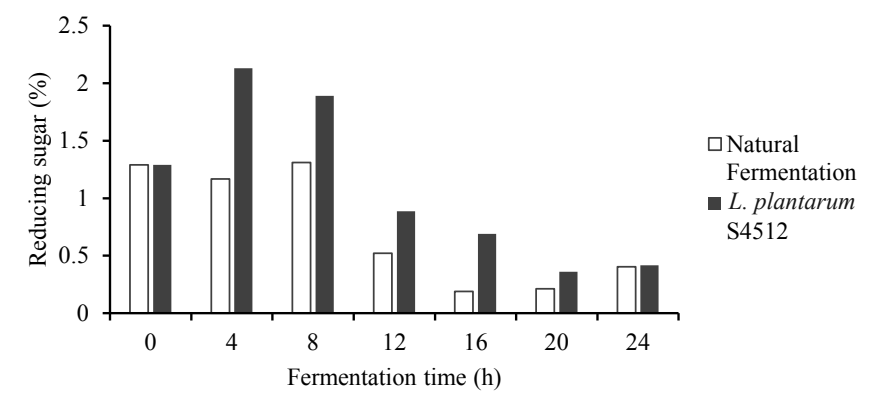

Figure 5. Reducing sugar of sorghum flour during natural sorghum fermentation and sorghum fermentation with addition of Lactrobacillus plantarum S4512

amino acids and soluble protein in fermented sorghum with Lactobacillus brevis increased compared to the ones in unfermented sorghum. This increase could be due to hydrolysis of insoluble proteins by bacterial proteolysis into peptide and amino acids. However, there was a decrease in soluble protein and amino acids contents in fermented sorghum with L. plantarum, Lactobacillus paracasei and Lactobacillus fermentum. This results indicates that soluble proteins were hydrolyzed to amino acids by bacterial proteases and peptidases, and these amino acids can be readily utilized by microorganism for their growth and metabolism activities.

The amount of soluble protein in the fermented sorghum is affected by the proteolytic activities produced by microorganisms in during fermentation and the rate of consumption of free amino acids for microbial growth and metabolism activities. It could be that higher microbial growth rate in natural sorghum fermentation compared to the one with addition of L. plantarum S4512 resulted in higher consumption of free amino acids and thus lower soluble protein content.

Mugula et al. (2003b) reported that the SDS-PAGE banding pattern indicated breakdown of high molecular mass protein in togwa fermentation. They also found that 
natural fermentation increased the content of glutamic acid, proline and ornithine, but the concentration of most of the free amino acids, including the essential amino acids, was reduced during both natural and controlled fermentation. This indicates the utilization of amino acids for growth and production of metabolites. Carreia et al. (2005) also noted the reduction of soluble protein and the increase in free amino acid in traditional sorghum fermentation. This supports the involvement of proteolytic enzymes in sorghum fermentation.

The increase in reducing sugar content in fermented sorghum is a consequence of starch hydrolysis. The simpler sugars then can be utilized by microorganism to growth and metabolism activities, thus reduce the reducing sugar content. The decreased in reducing sugar content of fermented sorghum is in agreement with the ${ }^{1} \mathrm{H}$ NMR spectra which show decreases of glucose., fructose and maltose signals (Correia et al., 2005). Thus the concentration of reducing sugar in fermented sorghum flour is affected by the activity of microbial amylases during fermentation and the rate of fermentable sugars consumption for growth and production of metabolites.

Correira et al. (2010) reported that sorghum fermented with Lactobacillus brevis had higher reducing sugar content and total soluble sugars, and lower total starch content compared to the ones in unfermented sorghum. It seems that L. brevis has amylolytic and proteolytic activities simultaneously. Proteolytic attack to the proteins could make starch more accessible to bacterial amylases resulted in higher reducing sugar content. Elkhalifa et al. (2006) suggested that starch granules in unfermented sorghum flours are completely enclosed in a very compact protein matrix. The protein barrier surrounding the strach granule may reduce the hydrolysis of native starch by amylolytic enzyme. The present of proteases degrades the protein matrix and enhanced starch hydrolysis by increasing surface area and enabling starch to interact with amylases, thus increased the reducing sugar content.

\section{CONCLUSIONS}

Addition of L. plantarum S4512 in the sorghum flour fermentation increased the initial population of lactic acid bacteria and proteolytic bacteria, and significantly suppressed the population coliform. The production of acid increased significantly, and the acid content of fermented sorghum with addition of L. plantarum S4512 was doubled of that in the natural fermentation. Both natural sorghum fermentation and that with addition of proteolytic L. plantarum S4512 showed some proteolytic activities during fermentation.

\section{REFERENCES}

Abdel-Rahman, I.E., Hamad, S.H., Osman, M.A. and Dirar H.H. (2010). Characterization and Distribution of Microorganism Assosiated with Kisra Bread from Three Shorgum Varieties in Sudan. Current Research in Bacteriology. Asian network For Scientific Information. ISSN 1994-5426.

Angali, C. (1998). Sorghum carbohydrates- a review. Plant Foods for Human Nutrition 52: 77-83.

Anonim (1990). Official Methods of Analysis, $18^{\text {th }}$ Edition. Association of Official Analytical Chemists, Washington, DC.

Bruno, M.A., Lazza, C.M., Errasti, M.A., Lopez, L.M.I., Caffini, N.O. and Pardo, M.F. (2010). Milk clotting and proteolytic activity of an enzyme preparation from Bromelia hieronymi fruits. Journal of Food Science and Technology 43: 659-701.

Correia, I., Nunes, A., Duarte, I.F., Barros, A.S., and Delgadillo, I. (2005). Sorghum fermentation followed by spectroscopic techniques. Food Chemistry 90: 853859.

Corrieia, I., Nunes, A., Guedes, S., Barros, A.S. and Delgadillo, I. (2010). Screening of lactic acid bacteria potentially useful for sorghum fermentation. Journal of Cereal Science 52: 9-15.

De Mesa-Stonestreet, N.J., Alavi, S. and Bean, S.R., (2010). Sorghum protein: the concentration, isolation, modification and food applications of Kafirins. Journal of Food Science 75: R90-R104.

Duodu, K.G., Belton, P.S., Tylor, J.R.N. and Hamaker, B.R. (2003). Factor affecting sorghum protein digestability. Journal of Cereal Science 38: 117-131.

Elkhalifa, A.O., Schiffler, B. and Bernhardt, R. (2005). Effect of fermentation on the functional properties of sorghum flour. Food Chemistry 92: 1-5.

Elkhalifa, A.O., Bernhardt, R., Bonomi, F., Iametti, S., Pagani, M.A. and Zardi, M. (2006). Fermentation modifies protein/protein and protein/starch interactions in sorghum dough. European Food Research and Technology 222: 559-564.

Hassan, I.A.G. and El-Tinay, A.H. (1995). Effect of fermentation on tannin content and in-vitro protein and starch digestibility of two sorghum cultivars. Food Chemistry 53: 149-151.

Hidayah, Z. (2010). Microbiological, Chemical, Physical Changes and In-Vitro Starch Digestibility of Sorghum 
Flour Fiermented Spontenously and by Lactic Acid Bacteria. Master Thesis. Food Science and Technology Study Program. Gadjah Mada University. Yogyakarta, Indonesia.

Kunene, N.F., Hastings, J.W. and Holy, A. (1999). Bacterial population associated with a sorghum-based fermented weaning cereal. International Journal of Food Microbiology 49:75-83.

Mohammed, S.I., Steenson, L.R., Kirleis, A.W. (1991). Isolation and characterization of microorganisms associated with the traditional sorghum fermentation for production of Sudanese Kisra. Applied and Enviromental Microbiology 57: 2529-2533.

Mugula, J.K., Nnko, S.M.A., Narvhus, J.A. and Sorhaug, T. (2003a). Microbiological and fermentation characteristic of Togwa, a Tanzanian fermented Food. International Journal of Food Microbiology 83:187199.
Mugula, J.K., Sorhaug, T. and Stepaniak, L. (2003b). Proteolytic activities in Togwa, a Tanzanian fermented food. International Journal of Food Microbiology 84: 1-12.

Muyanja, C.M.B.K., Narvhus, J.A., Treimo, J. and Langsurd, T. (2003). Isolation, characterization and identification of lactic acid bacteria from bushera: a Ugandan traditional fermented beverage. International Journal of Food Microbiology 80: 201-210.

Nabrdalik, M., Grata, K. and Latala, A. (2010). Proteolytic cctivity of Bacillus cereus strains. Proceeding of ECOpole 4: 273-277.

Ray, B. (1996). Fundamental Food Microbiology. CRC Press, USA.

Zhang, G. and Hamaker B.R. (1998). Low $\alpha$-amylase starch digestibility of cooked sorghum flours and the sffect of protein. Cereal Chemistry 75: 710-713. 